\title{
Rhodococcus luteus nom. nov. and Rhodococcus maris nom. nov.
}

\author{
O. A. NESTERENKO, T. M. NOGINA, S. A. KASUMOVA, E. I. KVASNIKOV, ANd S. G. BATRAKOV \\ D. K. Zabolotny Institute of Microbiology and Virology of the Academy of Sciences of the Ukrainian SSR, \\ 252143, Kiev, USSR
}

\begin{abstract}
Two groups of bacteria isolated from natural substrates were assigned to the genus Rhodococcus Zopf 1891, emend. Goodfellow and Alderson 1977. We propose the name Rhodococcus luteus nom. nov. for the first group, which corresponds to the description of the organism previously known as "Mycobacterium luteum" Söhngen 1913. The type strain of $R$. luteus is IMV 385 (= AUCNM A-594). The name proposed for the second group of strains, which corresponds to the description of the organism previously known as "Flavobacterium maris" Harrison 1929, is Rhodococcus maris nom. nov. The type strain of $R$. maris is IMV 195 (= AUCNM A-593). The properties of the two species are described, and the characters useful for the identification of the species are given.
\end{abstract}

From soils of the Soviet Union and from skins and the intestinal tracts of carp (Cyprinus carpio), two groups of bacteria, distinguishable by their morphological and colonial characters, were isolated on mineral salt agar enriched with $n$-alkanes. These isolates were assigned to the genus Rhodococcus Zopf 1891, as emended by Goodfellow and Alderson (11) to include strains previously identified either as members of the genus "Gordona" (42) or of the "rhodochrous" complex (7). (Names in quotation marks were not included on the Approved Lists of Bacterial Names [37] and have not been validly published since 1 January 1980; therefore, they have no standing in bacterial nomenclature.)

Among the various characters used in describing these organisms, chemical markers are of special value in distinguishing Rhodococcus from related genera $(13,28)$. Nocardiae, mycobacteria, rhodococci, and true corynebacteria contain meso-diaminopimelic acid (DAP), arabinose, and galactose in their whole-cell hydrolysates (cell wall chemotype IV) (27), whereas brevibacteria have only meso-DAP, and arthrobacters contain no meso-DAP or arabinose (13, $23,32,35,44)$. The above-mentioned organisms can be distinguished from one another by thinlayer chromatography of ethanol-ether extracts of their cells. The true corynebacteria, nocardiae, and rhodococci contain a characteristic lipid component (LCN-A), composed of free mycolic acid $(14,23,30)$, whereas mycobacteria, brevibacteria, and arthrobacters do not $(23,30$, 32). The LCN-A of Nocardia has a higher $R_{f}$ value than that of many rhodococci; the lowest mobility of LCN-A was observed with the Corynebacterium strains $(23,30,32)$. Differences in mobility of LCN-A on thin-layer chromatogra- phy depend on differences in the molecularweight ranges of the free mycolic acids: Nocardia, 48 to 58 carbons; Rhodococcus, 34 to 50 carbons; and Corynebacterium, 22 to 38 carbons $(2,28,29)$. Thus, the $R_{f}$ value of LCN-A may be useful in distinguishing among nocardiae, rhodococci, and true corynebacteria.

Analyses of other types of lipids may also be valuable in differentiating rhodococci from related bacteria. Menaquinone analyses, for example, indicate that representatives of some animal corynebacteria, rhodococci (including the type species, Rhodococcus rhodochrous; see 11), and Brevibacterium linens all have menaquinones with eight isoprene units and one hydrogenated double bond [MK-8( $\left.\left.\mathrm{H}_{2}\right)\right]$ as the prevalent type; arthrobacters, glutamic acid-producing saprophytic corynebacteria, and mycobacteria have MK-9 $\left(\mathrm{H}_{2}\right)$ as the main menaquinone component; in contrast, representatives of Nocardia have MK-8 $\left(\mathrm{H}_{4}\right)$ as the main menaquinone component (28). The non-hydroxylated fatty acids of nocardiae, rhodococci, and mycobacteria contain high proportions of straight-chain and unsaturated acids and of 10-methyloctadecanoic (tuberculostearic) acid, whereas most true corynebacteria do not contain tuberculostearic acid; the simple fatty acids of arthrobacters and $B$. linens are composed mainly of iso- and anteiso-acids (12, 28).

Analyses of deoxyribonucleic acid base compositions revealed that the guanine-plus-cytosine contents of the deoxyribonucleic acids of Mycobacterium, Nocardia, Rhodococcus, Arthrobacter, and $B$. linens are in the range of 60 to $70 \mathrm{~mol} \%$, whereas those of true corynebacteria range from 48 to $59 \mathrm{~mol} \%(13,28)$.

In the study reported here, the characters and 
the taxonomic positions of the isolated strains were determined.

\section{MATERIALS AND METHODS}

Bacterial strains. A list of the strains studied and their sources are given in Tables 1 and 2. The strains were isolated on mineral salt agar $\left(\mathrm{KNO}_{3}, 1 \mathrm{~g} ; \mathrm{MgSO}_{4}\right.$, $0.1 \mathrm{~g} ; \mathrm{Na}_{2} \mathrm{HPO}_{4}, 0.6 \mathrm{~g} ; \mathrm{KH}_{2} \mathrm{PO}_{4}, 0.14 \mathrm{~g} ; \mathrm{NaCl}, 1 \mathrm{~g}$; mixture of $n$-alkanes $\left(\mathrm{C}_{12}\right.$ to $\left.\mathrm{C}_{22}\right), 20 \mathrm{~g}$; tap water, 500 $\mathrm{ml}$; distilled water, $500 \mathrm{ml}$ ) by the method of Yamada et al. (45). The temperature of incubation was $28^{\circ} \mathrm{C}$.

Morphological and cultural tests. The cell form and size and the reaction to the Gram stain were determined on smears from 16- to 24-h-old, 72-h-old, and 12-day-old cultures, on nutrient agar (NA) (4), glycerol agar (GA) (17), and wort agar (WA) (4) slants. Motility and acid fastness were tested in cultures grown on NA for $18 \mathrm{~h}$. The mode of cell division was studied by time-lapse microscopy. Microcultures of the bacteria were made on NA by the method of Komagata et al. (24). The macroscopic appearance of the growth was examined on NA plates and on NA, GA, and WA slants 2 weeks after inoculation.

Physiological tests. Hugh and Leifson's (21) test was used to determine the fermentation or oxidation of glucose. The production of acid from different carbohydrates, the utilization of organic acids, the production of urease, the reduction of nitrate to nitrite, and the decomposition of casein, guanine, hypoxanthine, starch, tyrosine, and xanthine were determined by the methods of Gordon and Smith $(18,19)$ and Gordon and Mihm $(16,17)$. Phosphatase production was determined by the method of Giane-Williams and Skerman (10). The hydrolysis of Tweens was investigated by the method of Sierra (36), and the utilization of acetamide and benzamide as sole carbon and nitrogen sources was studied by the method of Tsukamura (42). The production of $p$-nitrophenoloxidase was determined by the method of Bönicke and Juhasz (6). The ability to utilize $n$-alkanes was studied on the mineral salt agar mentioned above and by the method described by Kvasnikov et al. (26). Descriptions of the other tests utilized have been previously published $(4,38)$.

Chemotaxonomic tests. The monosaccharides and the form of DAP in whole-cell hydrolysates were investigated as previously reported (31). Lipid LCN-A was detected by the method of Mordarska et al. (30). For preparation of the chromatographic plates, we used the 1- to 2-h fraction (or 10 to $30 \mu \mathrm{m}$ ) of silica gel

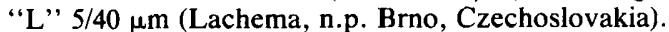
The chromatograms were developed in the system $n$ hexane-diethyl ether-glacial acetic acid (50:50:2, vol/ vol) (23). The spots of LCN-A detected in the bacteria under investigation were always compared with those of three reference strains: Rhodococcus sp. (" ' $M$.' rhodochrous') strain NCTC $576, R$. erythropolis ( $N$. calcarea) NCIB 8863, and " $C$. divaricatum" (B. divaricatum) NCIB 9379. Free mycolic acids of Rhodococcus sp. strain NCTC 576 contains from 38 to 47 carbon atoms (22), and those from $R$. erythropolis NCIB 8863 contain 34 to 46 carbons (29). " $C$. divaricatum" NCIB 9379 contains the mycolic acid analogs characteristic of $C$. diphtheriae: 26 to 38 carbons $(23,28)$. The lipid LCN-A of Rhodococcus sp. strain NCTC 576 has a high $R_{f}$ value $(0.59)$, and that of " $C$. divaricatum" NCIB 9379 has a low value (0.54); the LCN-A of $R$.
TABLE 1. Isolated strains used in this study

\begin{tabular}{|c|c|c|}
\hline Serial no. & Laboratory no. ${ }^{a}$ & Site of isolation \\
\hline \multicolumn{3}{|c|}{ Rhodococcus luteus (group I bacteria) } \\
\hline 1 & IMV 8 & Soil $^{b}$ \\
\hline 2 & IMV 21 & Soil \\
\hline 3 & IMV 24 & Soil \\
\hline 4 & IMV 27 & Soil \\
\hline 5 & IMV 68 & Soil \\
\hline 6 & IMV 103 & Soil \\
\hline 7 & IMV 111 & Soil \\
\hline 8 & IMV 115 & Soil \\
\hline 9 & IMV 120 & Soil \\
\hline 10 & IMV 158 & Soil \\
\hline 11 & IMV 163 & Soil \\
\hline 12 & IMV 177 & Soil \\
\hline 13 & IMV 202 & Soil \\
\hline 14 & IMV 206 & Soil \\
\hline 15 & IMV 242 & Soil \\
\hline 16 & IMV 269 & Soil \\
\hline 17 & IMV 270 & Skin of carp \\
\hline 18 & IMV 323 & Soil \\
\hline 19 & IMV 333 & Soil \\
\hline 20 & IMV 372 & Soil \\
\hline 21 & IMV 374 & Intestinal tract of carp \\
\hline 22 & IMV 385 & Soil \\
\hline 23 & IMV 401 & Soil \\
\hline 24 & IMV 406 & Soil \\
\hline 25 & IMV 416 & Intestinal tract of carp \\
\hline 26 & IMV 417 & Soil \\
\hline 27 & IMV 419 & Soil \\
\hline 28 & IMV 427 & Soil \\
\hline 29 & IMV 445 & Soil \\
\hline 30 & IMV 455 & Soil \\
\hline 31 & IMV 462 & Soil \\
\hline 32 & IMV 604 & Soil \\
\hline \multicolumn{3}{|c|}{ Rhodococcus maris (group II bacteria) } \\
\hline 33 & IMV 195 & Soil \\
\hline 34 & IMV 217 & Soil \\
\hline 35 & IMV 277 & Soil \\
\hline 36 & IMV 283 & Intestinal tract of carp \\
\hline 37 & IMV 324 & Soil \\
\hline 38 & IMV 330 & Skin of carp \\
\hline
\end{tabular}

${ }^{a}$ IMV, Institute of Microbiology and Virology, Kiev, USSR.

${ }^{b}$ Soils, as a rule, were impregnated with oil.

erythropolis NCIB 8863 occupies an intermediate position (0.56).

The deoxyribonucleic acid base composition was determined by the method described by Sukapure et al. (41).

The simple fatty acids were detected by the method described by Andreev and Galchenko (3). Gas-liquid chromatography was performed with a Hewlett-Packard $5380 \mathrm{~A}$ apparatus.

Menaquinones were analyzed by the method of Batrakov et al. (5).

Identification of strains. The 66 isolates were divided into two groups on the basis of their morphological, cultural, and physiological characteristics. The properties of the groups were compared with those of the type strains (Table 2$)(11,34)$ of most of the currently recognized Rhodococcus species. 
TABLE 2. Culture collection strains used in this study

\begin{tabular}{|c|c|c|c|c|}
\hline $\begin{array}{l}\text { Serial } \\
\text { no. }\end{array}$ & $\begin{array}{l}\text { Laboratory } \\
\text { no. }\end{array}$ & Names & Strain $^{a}$ & Source \\
\hline 1 & IVM 733 & B. divaricatum & C94 (= NCIB 9379) & $\begin{array}{l}\text { D. Jones, School of Biological Sciences, The } \\
\text { University, Leicester, England }\end{array}$ \\
\hline 2 & IMV 734 & "B. maris" & AUCNM B-464 & AUCNM \\
\hline 3 & IMV 735 & "M. luteum" & AUCNM B-868 & AUCNM \\
\hline 4 & IMV 736 & "M. luteum" & 587 & $\begin{array}{l}\text { R. E. Gordon, Waksman Institute of } \\
\text { Microbiology, Rutgers, The State } \\
\text { University, New Brunswick, N.J. }\end{array}$ \\
\hline 5 & IMV 737 & R. bronchialis & $\begin{array}{l}\text { N654 (= ATCC } 25592 \\
\quad=\text { NCTC } 10667)^{b}\end{array}$ & $\begin{array}{l}\text { M. Goodfellow, Department of } \\
\text { Microbiology, The Medical School, The } \\
\text { University, Newcastle upon Tyne, } \\
\text { England }\end{array}$ \\
\hline 6 & IMV 738 & R. coprophilus & $\begin{array}{l}\text { CUB } 687(=\text { ATCC } \\
\qquad 9080)^{b}\end{array}$ & $\begin{array}{l}\text { T. J. Rowbotham, Postgraduate School of } \\
\text { Studies in Biological Sciences, University } \\
\text { of Bradford, England }\end{array}$ \\
\hline 7 & IMV 739 & $R$. corallinus & $\begin{array}{l}\text { N657 }(=\text { ATCC } 25593 \\
\quad=\text { NCTC } 10668^{b}\end{array}$ & M. Goodfellow \\
\hline 8 & IMV 740 & R. equi & $\begin{array}{l}\mathrm{R} 71(=\mathrm{ATCC} 25729 \\
\quad=\text { NCTC } 1621)^{b}\end{array}$ & M. Goodfellow \\
\hline 9 & IMV 741 & R. erythropolis & $\begin{array}{l}\text { AJ } 9126(=\text { ATCC } 4277 \\
=\text { NCIB } 9158)^{b}\end{array}$ & $\begin{array}{l}\text { I. Komura, Central Research Laboratories, } \\
\text { Ajinomoto Co., Inc., Kawasaki, Japan }\end{array}$ \\
\hline 10 & IMV 742 & $\begin{array}{l}\text { R. erythropolis ( } N \text {. } \\
\text { calcarea) }\end{array}$ & N41 ( = NCIB 8863) & M. Goodfellow \\
\hline 11 & IMV 743 & R. rhodnii & N445 (= NCIB 11279) & M. Goodfellow \\
\hline 12 & IMV 744 & R. rhodochrous & ATCC $13808^{b}$ & $\begin{array}{l}\text { M. Tsukamura, Chuba Chest Hospital, Obu, } \\
\text { Aichi, Japan }\end{array}$ \\
\hline 13 & IMV 745 & R. ruber & M-1 & M. Tsukamura \\
\hline 14 & IMV 746 & R. rubropertinctus & $\begin{array}{l}\text { N4 }(=\text { ATCC } 14352 \\
=\text { NCIB 9664 })^{b}\end{array}$ & M. Goodfellow \\
\hline 15 & IMV 747 & Rhodococcus sp. & NCTC 576 & NCTC \\
\hline 16 & IMV 748 & R. terrae & $\begin{array}{l}\text { N659 }(=\text { ATCC } 25594 \\
\quad={\text { NCTC } 10669)^{b}}^{b}\end{array}$ & M. Goodfellow \\
\hline
\end{tabular}

${ }^{a}$ AUCNM, All-Union Collection of Nonpathogenic Microorganisms, Moscow, USSR; NCIB, National Collection of Industrial Bacteria, Aberdeen, Scotland; ATCC, American Type Culture Collection, Rockville, Md.; NCTC, National Collection of Type Cultures, London, England; CUB, Actinomycete Culture Collection, University of Bradford, Bradford, England; AJ, Culture Collection of Central Research Laboratories of Ajinomoto Co., Inc., Kawasaki, Japan; C, N, and R, Laboratory numbers of strains from D. Jones and M. Goodfellow.

${ }^{b}$ Type strain (37).

\section{RESULTS AND DISCUSSION}

Forty-nine of the isolates were placed in group I, and the following description is based on 32 of these strains.

Cell morphology of group I bacteria. Smears of cultures grown on GA and NA for 16 to $24 \mathrm{~h}$ showed straight or slightly curved rods $(0.6$ to $1.0 \mu \mathrm{m}$ by 3.0 to $6.0 \mu \mathrm{m}$ ) arranged in an angular or parallel fashion. Rods and branching filaments $(15$ to $16 \mu \mathrm{m})$ rarely occurred. On WA, the 16- to 24-h-old cultures consisted, as a rule, of rods that were shorter than the cells grown on NA and GA (1.5 to $2.5 \mu \mathrm{m}$ ); many coccoid forms were also found. The morphological transformation of cells during growth on agar slants depended on the composition of the medium. Thus, the rod-shaped cells cultivated on WA generally transformed rapidly to the coccoid form. However, on NA and GA the rods became shorter but ordinarily did not become coccoid.

As shown by time-lapse microscopy, the rodshaped bacteria elongated and bent within $16 \mathrm{~h}$ of cultivation (Fig. 1); sometimes branches were formed. During elongation, septa were formed, and $16 \mathrm{~h}$ later, filaments fragmented into rodshaped elements. The latter then divided, as a rule, by snapping or bending and formed characteristic $\mathrm{V}$ forms. In $48 \mathrm{~h}$, the microcolony consisted of rods ( 2 to $4 \mu \mathrm{m}$ in length) characteristically arranged in Vs.

Group I bacteria were gram-positive, were not (or rarely only partly) acid-fast, and were nonmotile; endospores were not formed.

Cultural characteristics of group I bacteria. Growth on GA and WA slants was usually abundant, butyrous or mucoid, and intensely yellow; growth on NA slants was moderate or poor, butyrous, and deep yellow to pale orange; 

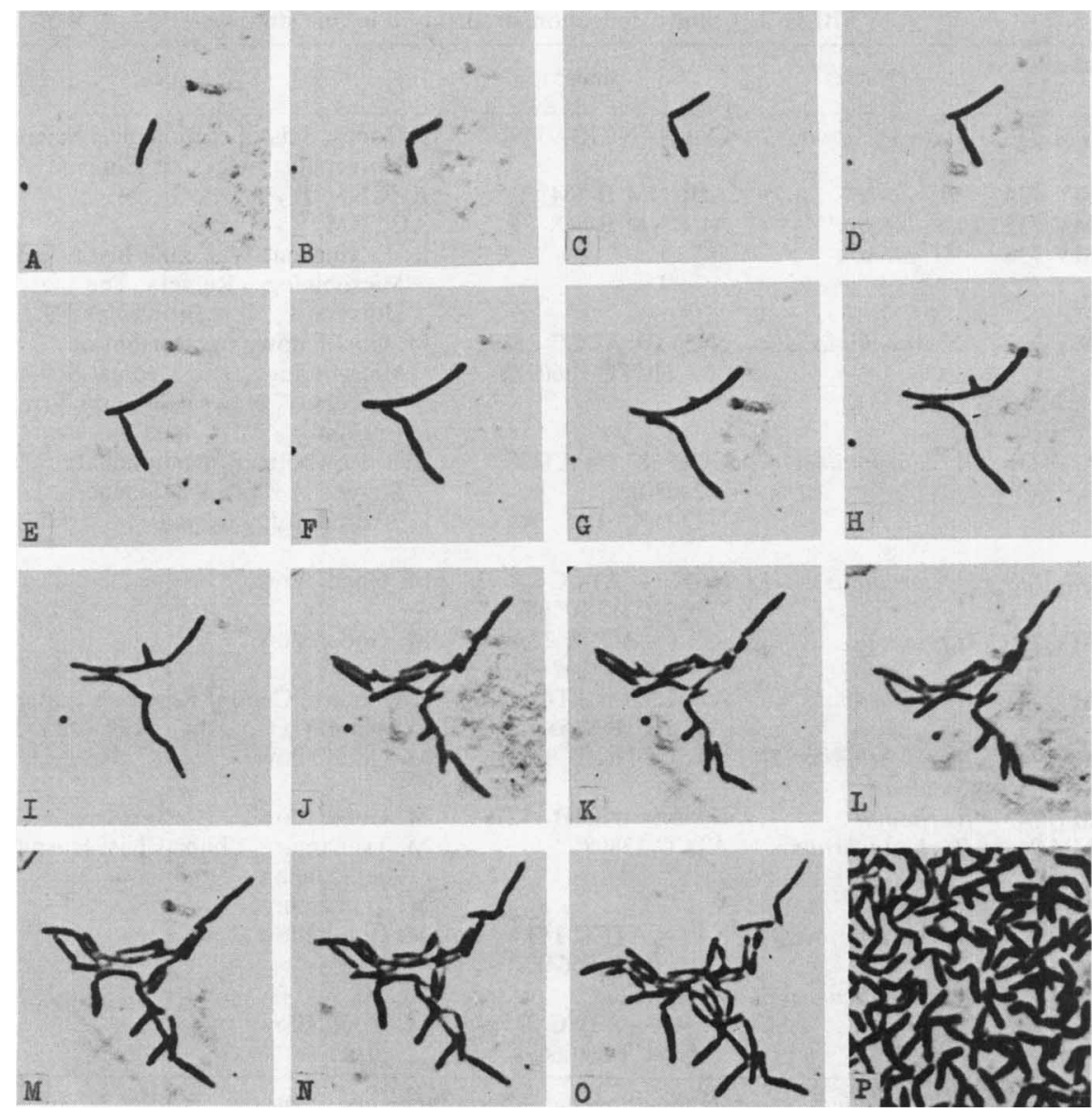

FIG. 1. Growth of $R$. luteus strain 177 on NA at $28^{\circ} \mathrm{C}$. Phase contrast, $\times 2,600 . \mathrm{A}, 5 \mathrm{~h} ; \mathrm{B}, 7 \mathrm{~h} ; \mathrm{C}, 9 \mathrm{~h} ; \mathrm{D}, 11 \mathrm{~h}$; E, 12 h; F, 14 h; G, 15 h; H, 16 h; I, 16 h 45 min; J, 18 h 50 min; K, 19 h; L, 20 h; M, 21 h; N, 21 h 40 min; O, 23 h; $\mathrm{P}, 48 \mathrm{~h}$.

on Löwenstein-Jensen medium growth was abundant and yellow-orange. Colonies on the surfaces of NA plates were flat, opaque, raised, glistening, and smooth; colonies that had raised centers and that were opaque and smooth or gently folded also occurred. In nutrient broth, a membrane formed on the surface and the broth remained clear.

Physiological and chemotaxonomic characteristics of group I bacteria. The results of the physiological tests are listed in Tables 3-5. All of the strains actively oxidized glucose. Catalase was produced. Casein ( $91 \%$ of the strains were negative), cellulose, guanine, hypoxanthine $(88 \%)$, starch, tyrosine, and xanthine were not attacked, but urea was. Tweens $20,40,60$, and 80 were hydrolyzed. Acetylmethylcarbinol, indole, phosphatase ( $94 \%$ of the strains were negative), and $p$-nitrophenoloxidase were not produced; $\mathrm{NH}_{3}$ was produced from peptone. No growth occurred with acetamide or benzamide as a sole carbon and nitrogen source. Benzoate, oxalate, and tartrate were not utilized. Acetate, $\gamma$-aminobutyrate, butyrate ( $94 \%$ of the strains were positive), cis-aconitate, citrate, fumarate, $\alpha$-ketoglutarate, lactate, malate, pyruvate, and succinate were utilized. Acid was produced from arabinose, fructose, galactose, glucose, glycerol, mannitol, mannose, sorbitol, sucrose, and xylose ( $87 \%$ of the strains were positive). No acid was produced from adonitol, cellobiose, dulcitol, inositol, lactose, maltose, $\alpha$-methyl-Dglucoside, raffinose ( $97 \%$ of the strains were negative), rhamnose, or salicin. Growth occurred in the presence of 5 and $7 \% \mathrm{NaCl}$ and of $\mathrm{C}_{9}$ to $\mathrm{C}_{17}, \mathrm{C}_{19}$, and $\mathrm{C}_{23} n$-alkanes. No growth occurred with methane, ethane, or $\mathrm{C}_{8} n$-alkane. No growth occurred at $45^{\circ} \mathrm{C}$. Nitrate was reduced to nitrite $(85 \%$ of the strains were negative). Litmus milk became alkaline ( $91 \%$ of the strains were positive). Properties such as the liquefaction of gelatin, the production of $\mathrm{H}_{2} \mathrm{~S}$, 
TABLE 3. Tests positive with $R$. luteus (group I bacteria), " $M$. luteum" AUCNM B-868, and " $M$. luteum" 587

Acetate utilization

Acid from the following carbohydrates

D-(-)-Arabinose

Fructose

Galactose $^{a}$

Glucose

Glycerol

Mannitol

Mannose

Sorbitol

Sucrose

cis-Aconitate utilization

$\gamma$-Aminobutyrate utilization ${ }^{a}$

Catalase production

Cell wall chemotype $\mathrm{IV}^{b}$

Citrate utilization

Decomposition of Tweens 20, 40,60, and 80

Fumurate utilization

Gram positive

Growth intensely yellow on NA, GA, and WA without aerial mycelium

Growth with $\mathrm{C}_{9}$ to $\mathrm{C}_{17}, \mathrm{C}_{19}, \mathrm{C}_{23} n$-alkanes

Growth with $7 \% \mathrm{NaCl}$

$\alpha$-Ketoglutarate utilization

Lactate utilization

Malate utilization

Oxidation of glucose in Hugh and Leifson O-F medium

Presence of lipid LCN-A

Production of $\mathrm{NH}_{3}$ from peptone

Pyruvate utilization

Rod-like cells ( 3 to $16 \mu \mathrm{m}$ ) after 16 to $18 \mathrm{~h}$ of incubation on NA and GA

Succinate utilization

Urease production

a "Mycobacterium luteum" 587 is negative.

${ }^{b}$ Cell wall chemotype IV: arabinose, galactose and meso-DAP are in whole cell hydrolysates.

and growth in the presence of $C_{3}, C_{6}$, and $C_{7} n$ alkanes were quite variable within the group (Table 5).

All strains contained meso-DAP, arabinose, and galactose in their cells as well as lipid LCNA that on plates with silica gel moved similarly to that from Rhodococcus sp. strain NCTC 576. The guanine-plus-cytosine content of the deoxyribonucleic acid of strain 385 was $64.1 \mathrm{~mol} \%$ by thermal denaturation. Fatty acid analysis of stationary-phase cells of strain 385 revealed that the main acids were (percentage of total detected): $\mathrm{C}_{14: 0}(12 \%), \mathrm{C}_{16: 1}(12 \%), \mathrm{C}_{16: 0}(20 \%), \mathrm{C}_{18: 1}$ $(22 \%)$, and $10 \mathrm{CH}_{3} \mathrm{C}_{18}(13 \%)$. Strain 385 contained, as the major component, menaquinone having eight isoprene units with one hydrogenated double-bond, MK-8 $\left(\mathrm{H}_{2}\right)$; small amounts of MK-7 $\left(\mathrm{H}_{2}\right)$ and traces of MK-8 were detected as well.

On the basis of the following characteristics, we classify these organisms as members of the genus Rhodococcus in the family Nocardiaceae (9, 11, 28): gram-positive, nonmotile, do not form endospores, aerobic, form a primary mycelium that soon fragments into rod-shaped elements, produce soft colonies without aerial hyphae, have a cell wall of chemotype IV, have a lipid LCN-A of the Rhodococcus type, have a guanine-plus-cytosine content of the DNA of $64.1 \mathrm{~mol} \%$, have fatty acids containing a high proportion of tuberculostearic acid $\left(10 \mathrm{CH}_{3} \mathrm{C}_{18}\right)$, straight-chain, and unsaturated acids, and have menaquinone $\mathrm{MK}-8\left(\mathrm{H}_{2}\right)$ as the major isopreno$\log$.

We compared the properties of group I bacteria with those of eight type strains and two reference strains of 10 established Rhodococcus species (Table 6) and concluded that the members of group I should be classified as a distinct species of Rhodococcus. As to selecting a name for these organisms, we should like to point out the following. The characters of the bacteria of

TABLE 4. Tests negative with $R$. luteus (group I bacteria), " $M$. luteum" AUCNM B-868, and " $M$. luteum" 587

Acetylmethylcarbinol production

Acid from the following carbohydrates:

Adonitol

Cellobiose

Dulcitol

Inositol

Lactose

Maltose $^{a}$

$\alpha$-Methyl-D-glucoside

Rhamnose

Salicin

Sorbose

Benzoate utilization ${ }^{a}$

Decomposition of the following substrates:

Cellulose

Guanine

Starch

Tyrosine $^{b}$

Xanthine

Endospore formation

Growth with:

Acetamide

Benzamide

Ethane

Methane

$\mathrm{C}_{8}$ n-alkane

Growth at $45^{\circ} \mathrm{C}$

Indole production

Motility

p-Nitrophenoloxidase production

Oxalate utilization ${ }^{a}$

Tartrate utilization

Methyl red test

a "M. luteum" 587 is positive.

$b$ "M. luteum" AUCNM B-868 is positive. 
TABLE 5. Tests giving different results with strains of $R$. luteus (group I bacteria)

\begin{tabular}{|c|c|c|c|c|c|}
\hline \multirow[b]{2}{*}{ Characteristic } & \multirow[b]{2}{*}{$\begin{array}{l}\text { No. of } \\
\text { strains } \\
\text { positive }\end{array}$} & \multicolumn{3}{|c|}{ Results with: } & \multirow[b]{2}{*}{$\begin{array}{l}\text { Serial no. of strains that gave } \\
\text { the less common result }\end{array}$} \\
\hline & & $\begin{array}{l}\text { Type strain } \\
\text { (IMV 385) }\end{array}$ & $\begin{array}{c}\text { "M. luteum" } \\
\text { AUCNM } \\
\text { B-868 }\end{array}$ & "M. luteum" & \\
\hline Acid from raffinose & $1 / 32$ & - & - & - & 28 \\
\hline Acid from xylose & $28 / 32$ & + & + & - & $15,18,24,31$ \\
\hline $\begin{array}{l}\text { Alkaline reaction in litmus } \\
\text { milk }\end{array}$ & $29 / 32$ & + & + & + & $11,19,23$ \\
\hline $\begin{array}{l}\text { Decomposition of casein } \\
\text { Decomposition of }\end{array}$ & $3 / 32$ & - & - & - & $25,26,30$ \\
\hline hypoxanthine & $4 / 32$ & + & + & - & $10,22,29,30$ \\
\hline Gelatin liquefaction & $12 / 32$ & - & - & - & $\begin{array}{l}5,6,10,17,18,19,20,21,24,28 \\
29,30\end{array}$ \\
\hline Nitrate reduction & $5 / 32$ & - & - & + & $1,5,9,13,16$ \\
\hline Production of $\mathrm{H}_{2} \mathrm{~S}$ & $12 / 32$ & + & + & + & $\begin{array}{l}2,3,7,12,13,19,20,22,23,25 \text {, } \\
26,32\end{array}$ \\
\hline Production of phosphatase & $2 / 32$ & - & - & - & 1,29 \\
\hline Utilization of butyrate & $30 / 32$ & + & + & + & 14,32 \\
\hline Growth with $\mathrm{C}_{3} n$-alkane & $19 / 32$ & + & Not tested & Not tested & $\begin{array}{l}4,6,9,13,14,16,18,23,24,26 \\
28,30\end{array}$ \\
\hline Growth with $\mathrm{C}_{6} n$-alkane & $25 / 32$ & + & Not tested & Not tested & $2,3,5,9,12,26,30$ \\
\hline Growth with $\mathrm{C}_{7}$ n-alkane & $11 / 32$ & - & Not tested & Not tested & $1,2,6,7,8,11,14,24,25,26,30$ \\
\hline
\end{tabular}

group I correspond to the description of " $M$. luteum" given by Söhngen (39) and later supplemented by Krasil'nikov (25). In Söhngen's report (39) we found nothing about the strains on which the author based his original description of "M. luteum," and a type or neotype strain of "M. luteum" has not been officially established (39, 40). According to Gordon and Mihm (16) and Gordon (15), Söhngen's strain 587 of " $M$. luteum" from Kluyver agrees with the original description of " $M$. luteum" (39), and it is accepted by Gordon and Mihm as authentic for the species. These authors (16) assigned this strain to " 'M.' rhodochrous" ("rhodochrous" complex).

The morphological, cultural, chemotaxonomic, and most of the physiological properties of group I bacteria are similar to those of the culture of " $M$. luteum" 587 studied in this work (Tables 3, 4, and 6). However, in contrast to strain 587 , our isolates did not utilize benzoate or oxalate but did utilize $\gamma$-aminobutyrate and did form acid from galactose and xylose (87\% of the strains were positive) but did not form acid from maltose. In contrast to the description of "M. luteum" by Krasil'nikov (25), group I bacteria did not peptonize milk. Group I bacteria are also very closely related to " $M$. luteum" AUCNM B-868 (Tables 3-6).

Thus, " $M$. luteum," corresponding to the isolates of group I, must be considered as a species of Rhodococcus (16; our data). However, "M. luteum" was not included on the Approved Lists (37), and hence it has no standing in nomenclature. Furthermore, since we here regard " $M$. luteum" as a member of the genus
Rhodococcus, it would serve no useful purpose to revive the name " $M$. luteum." Consequently, we propose the name Rhodococcus luteus for the group I bacteria. This name cannot be regarded as a new combination, and the organism cannot be regarded as a new species since it was already recognized as such by Söhngen in 1913. We therefore regard $R$. luteus as a new name, realizing that this use of "nom. nov." will require an amendment of rule $34 \mathrm{a}$ of the Bacteriological Code to accommodate this and similar situations.

Strain IMV 385 (= AUCNM A-594) is the type strain of $R$. luteus. The characters of this strain are given in Table 6 . In general, the description of IMV 385 agrees with the original description of " $M$. luteum" (39). However, in contrast to this description, but similar to strains AUCNM B-868 and 587 of " $M$. luteum," strain IMV 385 produces urease. In contrast to " $M$. luteum" 587, strain IMV 385 decomposes hypoxanthine, does not reduce nitrate to nitrite, does not utilize benzoate or oxalate but utilizes $\gamma$-aminobutyrate, and produces acid from galactose and $x y$ lose but does not form acid from maltose. The properties of strain IMV 385 are similar to those of $M$. luteum AUCNM B-868 except for its ability to decompose tyrosine (Table 6).

The members of $R$. luteus may be differentiated from the type or reference strains of 10 species of Rhodococcus by a number of tests (see Table 10).

The following description of group II bacteria is based on 6 of the 17 isolates placed in this group.

Cell morphology of group II bacteria. After 16 
to $18 \mathrm{~h}$ of incubation on NA, GA, and WA slants, the cells were short ovoids $(0.6$ to $1.0 \mu \mathrm{m}$ by 1.0 to $2.0 \mu \mathrm{m}$ ) arranged in an angular fashion.

Time-lapse microscopy revealed (Fig. 2) that the coccoid cells $(0.8 \mu \mathrm{m}$ in length) elongated to $2.0 \mu \mathrm{m}$ within $6 \mathrm{~h}$ of cultivation. The rods then divided by snapping, and $\mathrm{V}$ forms were produced. The angles between the attached daughter cells became smaller, and the cells were then arranged in parallel. After several divisions of the rods, microcolonies were produced. Growth and division of cells occurred at the edges of the colonies, but at the centers of the microcolonies, the cells did not elongate; with each new division, the cells became shorter and eventually transformed into coccoid forms. After 36 to $48 \mathrm{~h}$, the microcolonies consisted of short, straight rods and coccoid forms.

Group II organisms were gram-positive, were not acid-fast, were nonmotile, and did not form endospores.

Cultural characteristics of group II organisms. Growth on NA, GA, and WA slants was moderate or poor, butyrous, and orange. Colonies on the surface of NA were raised, butyrous, glistening, and circular with an entire edge. Nutrient broth became turbid.

Physiological and chemotaxonomic characteristics. The results of the physiological tests are listed in Tables 7-9. Growth occurred in the aerobic and anaerobic tubes of Hugh and Leifson medium, but as a rule, the indicator was not changed to the acid color. Catalase was pro- duced. Casein, cellulose, guanine, hypoxanthine, starch, tyrosine, and xanthine were not attacked. Acetylmethylcarbinol, indole, $p$-nitrophenoloxidase, phosphatase, and $\mathrm{H}_{2} \mathrm{~S}$ were not produced. Tweens $20,40,60$, and 80 were hydrolyzed. No growth occurred with either acetamide or benzamide $(84 \%$ of the strains were negative) as the sole carbon and nitrogen source. $\gamma$-Aminobutyrate, benzoate, cis-aconitate, $\alpha$-ketoglutarate, lactate, oxalate, and tartrate were not utilized. Acetate, butyrate, fumarate, malate, pyruvate, and succinate were utilized. Acid was produced from fructose, glucose, and glycerol. No acid was produced from adonitol, arabinose, cellobiose, dulcitol, galactose, inositol, lactose, maltose, mannitol, $\alpha-$ methyl-D-glucoside, raffinose, rhamnose, salicin, sorbitol, sorbose, sucrose ( $84 \%$ of the strains were negative), or xylose. Growth occurred in the presence of 5 and $7 \% \mathrm{NaCl}$ and of $\mathrm{C}_{6}, \mathrm{C}_{7}, \mathrm{C}_{8}$ ( $83 \%$ of the strains were positive), $\mathrm{C}_{9}$ to $\mathrm{C}_{17}$, $\mathrm{C}_{19}$, and $\mathrm{C}_{23} n$-alkanes. No growth occurred with methane or ethane. No growth occurred at $45^{\circ} \mathrm{C}$. Nitrate was reduced to nitrite. There was no change in litmus milk. The liquefaction of gelatin, the production of $\mathrm{NH}_{3}$ from peptone, the decomposition of urea, the utilization of citrate, and the production of acid from mannose were quite variable within the group (Table 9).

All strains contained meso-DAP, arabinose, and galactose in their whole-cell hydrolysates and had a lipid LCN-A chromatographically similar to that of $R$. erythropolis NCIB 8863.

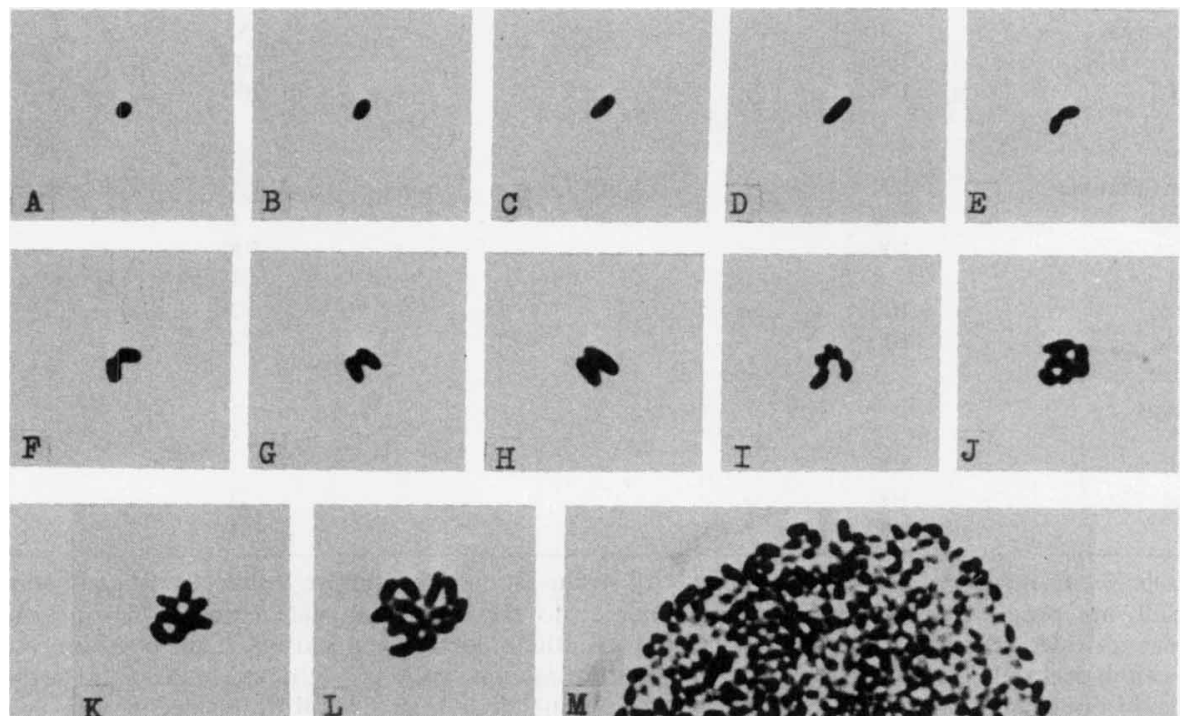

FIG. 2. Growth of $R$. maris strain 283 on NA at $28^{\circ} \mathrm{C}$. Phase contrast, $\times 2,800$. A, $0 \mathrm{~h} ; \mathrm{B}, 3 \mathrm{~h} ; \mathrm{C}, 4 \mathrm{~h} ; \mathrm{D}, 6 \mathrm{~h} ; \mathrm{E}$, $8 \mathrm{~h} ; \mathrm{F}, 9 \mathrm{~h} ; \mathrm{G}, 11 \mathrm{~h} ; \mathrm{H}, 12 \mathrm{~h} ; \mathrm{I}, 18 \mathrm{~h} ; \mathrm{J}, 23 \mathrm{~h} ; \mathrm{K}, 25 \mathrm{~h} ; \mathrm{L}, 30 \mathrm{~h} ; \mathrm{M}, 48 \mathrm{~h}$. 
The guanine-plus-cytosine content of the deoxyribonucleic acid of strain 195 was $73.2 \mathrm{~mol} \%$ by thermal denaturation. The main fatty acids of stationary-phase cells of this strain were (percentage of total detected): $\mathrm{C}_{16: 1}(12 \%), \mathrm{C}_{16: 0}$
(17\%), $\mathrm{C}_{17: 1}(16.5 \%), \mathrm{C}_{17: 0}(10 \%), \mathrm{C}_{18: 1}(14.5 \%)$, and $10 \mathrm{CH}_{3} \mathrm{C}_{18}(9.2 \%)$. Strain 195 possessed MK$8\left(\mathrm{H}_{2}\right)$ as the major isoprenolog, with smaller quantities of MK-6 and traces of MK-8.

On the basis of the following characteristics,

TABLE 6. Characteristics of the species of the genus Rhodococcus ${ }^{a}$

\begin{tabular}{|c|c|c|c|c|c|c|c|}
\hline \multirow[b]{2}{*}{ Character } & \multicolumn{2}{|c|}{ Group I } & \multirow[b]{2}{*}{$\begin{array}{c}\text { "M. luteum" } \\
\text { AUCNM } \\
\text { B-868 }\end{array}$} & \multirow[b]{2}{*}{ "M. luteum" } & \multicolumn{3}{|c|}{ Group II } \\
\hline & $\begin{array}{l}R . \text { luteus } \\
(32 \\
\text { strains })\end{array}$ & $\begin{array}{l}\text { R. luteus } \\
\text { IMV } 385\end{array}$ & & & $\begin{array}{l}R . \text { maris } \\
(6 \\
\text { strains })\end{array}$ & $\begin{array}{l}R . \text { maris } \\
\text { IMV } 195\end{array}$ & $\begin{array}{c}\text { R. maris } \\
\text { AUCNM } \\
\text { B-464 }\end{array}$ \\
\hline Nitrate reduction & $15^{b}$ & - & - & + & $100^{b}$ & + & + \\
\hline Gelatin liquefaction & 36 & - & - & - & 50 & - & - \\
\hline Litmus milk & $91^{c}$ & + & + & + & 0 & - & - \\
\hline \multicolumn{8}{|l|}{ Decomposition of: } \\
\hline Casein & 9 & - & - & - & 0 & - & - \\
\hline Hypoxanthine & 12 & + & + & - & 0 & - & - \\
\hline Tyrosine & $\mathbf{0}$ & - & + & - & 0 & - & - \\
\hline Tween 80 & 100 & + & + & + & 100 & + & + \\
\hline \multicolumn{8}{|l|}{ Production of: } \\
\hline $\mathrm{H}_{2} \mathrm{~S}$ & 36 & + & + & + & 0 & - & - \\
\hline $\mathrm{NH}_{3}$ from peptone & 100 & + & \pm & + & 50 & - & - \\
\hline$p$-Nitrophenoloxidase & 0 & - & - & - & 0 & - & - \\
\hline Phosphatase & 6 & - & - & - & 0 & - & - \\
\hline Urease & 100 & + & + & + & 33 & - & + \\
\hline \multicolumn{8}{|l|}{ Utilization of: } \\
\hline$\alpha$-Aminobutyrate & 100 & + & + & - & 0 & - & - \\
\hline Butyrate & 94 & + & + & + & 100 & + & + \\
\hline cis-Aconitate & 100 & + & + & + & 0 & - & - \\
\hline Citrate & 100 & + & + & + & 33 & - & - \\
\hline Fumarate & 100 & + & + & + & 100 & + & + \\
\hline$\alpha$-Ketoglutarate & 100 & + & + & + & 0 & - & - \\
\hline Lactate & 100 & + & + & + & 0 & - & + \\
\hline Malate & 100 & + & + & + & 100 & + & + \\
\hline Succinate & 100 & + & + & + & 100 & + & + \\
\hline \multicolumn{8}{|l|}{ Growth with/at } \\
\hline Acetamide & 0 & - & - & - & 0 & - & - \\
\hline Benzamide & 0 & - & - & - & 16 & - & - \\
\hline n-Alkanes $\mathrm{C}_{8}$ & 0 & - & - & - & 83 & + & + \\
\hline $\mathrm{C}_{13}$ & 100 & + & + & + & 100 & + & + \\
\hline $7 \% \mathrm{NaCl}$ & 100 & + & + & + & 100 & + & + \\
\hline $45^{\circ} \mathrm{C}$ & 0 & - & - & - & 0 & - & - \\
\hline \multicolumn{8}{|l|}{ Acid from: } \\
\hline D-(-)-Arabinose & 100 & + & + & + & 0 & - & - \\
\hline Galactose & 100 & + & + & - & 0 & - & - \\
\hline Glycerol & 100 & + & + & + & 100 & + & + \\
\hline Inositol & 0 & - & - & - & 0 & - & - \\
\hline Mannitol & 100 & + & + & + & 0 & - & - \\
\hline Mannose & 100 & + & + & + & 50 & - & - \\
\hline Raffinose & 3 & - & - & - & 0 & - & - \\
\hline Rhamnose & 0 & - & - & - & 0 & - & - \\
\hline Salicin & 0 & - & - & - & 0 & - & - \\
\hline Sorbitol & 100 & + & + & + & 0 & - & - \\
\hline Sucrose & 100 & + & + & + & 16 & - & - \\
\hline Xylose & 87 & + & + & - & 0 & - & - \\
\hline
\end{tabular}

a Symbols: +, Positive; -, negative; \pm , weak. All strains do not decompose cellulose, guanine, starch, and xanthine; do not produce acetylmethylcarbinol, indole; do not utilize benzoate (except " $M$. luteum" 587 ), oxalate (except "M. luteum" 587), or tartrate, but do utilize acetate and pyruvate; do not form acid from adonitol, cellobiose, dulcitol, lactose, maltose (except " $M$. luteum" 587), $\alpha$-methyl-D-glucoside, or sorbose, but do form acid from glucose and fructose; all are negative in the methyl red test; all strains decompose Tweens 20 , 40 , and 60 , produce catalase, and grow with $5 \% \mathrm{NaCl}$.

$b$ Percentage of strains positive.

${ }^{c}$ Litmus milk turns alkaline. 
group II bacteria may be classified in the genus Rhodococcus in the family Nocardiaceae $(9,11$, 13): gram-positive, nonmotile, pleomorphic, do not form endospores, produce soft colonies without aerial mycelium, and possess a cell wall of chemotype IV, a lipid LCN-A of the $R$. erythropolis NCIB 8863 type, a guanine-pluscytosine content of the deoxyribonucleic acid of $73.2 \mathrm{~mol} \%$, fatty acids containing a high proportion of tuberculostearic acid, straight-chain, and

TABLE 6-Continued

\begin{tabular}{|c|c|c|c|c|c|c|c|c|c|}
\hline $\begin{array}{c}R . \\
\text { rhodochrous } \\
\text { ATCC } 13803\end{array}$ & $\begin{array}{c}R . \\
\text { bronchialis } \\
\text { ATCC } \\
25592\end{array}$ & $\begin{array}{c}R . \\
\text { corallinus } \\
\text { ATCC } \\
25593\end{array}$ & $\begin{array}{c}R . \\
\text { erythropolis } \\
\text { ATCC } 4277\end{array}$ & $\begin{array}{l}R . \text { equi } \\
\text { ATCC } \\
25729\end{array}$ & $\begin{array}{l}\text { R. rhodnii } \\
\text { NCIB } \\
11279\end{array}$ & $\begin{array}{l}\text { R. ruber } \\
\text { M-1 }\end{array}$ & $\begin{array}{c}R . \\
\text { rubropertinctus } \\
\text { ATCC } 14352\end{array}$ & $\begin{array}{l}\text { R. terrae } \\
\text { ATCC } \\
25594\end{array}$ & $\begin{array}{c}R . \\
\text { coprophilus } \\
\text { ATCC } \\
29080\end{array}$ \\
\hline+ & + & + & - & + & + & + & + & + & + \\
\hline- & - & - & - & - & - & - & - & - & - \\
\hline+ & + & + & + & + & + & + & + & + & + \\
\hline- & - & - & - & - & - & - & - & - & - \\
\hline- & - & - & - & - & - & - & - & - & - \\
\hline+ & - & - & + & - & + & - & - & - & - \\
\hline+ & + & \pm & + & + & - & + & + & - & + \\
\hline- & + & - & - & - & - & - & - & - & - \\
\hline+ & - & + & \pm & - & \pm & + & - & + & \pm \\
\hline+ & + & - & + & - & - & + & + & - & - \\
\hline- & + & - & - & - & - & - & - & - & - \\
\hline- & + & + & + & + & + & - & - & + & - \\
\hline- & - & - & + & \pm & - & + & - & - & - \\
\hline+ & + & + & + & + & + & + & + & + & + \\
\hline- & - & + & + & - & - & + & + & \pm & - \\
\hline+ & + & + & + & - & - & + & + & + & - \\
\hline+ & + & + & + & + & + & + & + & + & - \\
\hline+ & - & + & - & - & - & - & + & + & - \\
\hline+ & + & + & + & + & + & \pm & + & + & + \\
\hline+ & + & + & + & + & + & + & + & + & - \\
\hline+ & + & + & + & + & + & + & + & + & - \\
\hline \pm & - & - & + & + & - & \pm & + & - & - \\
\hline- & - & - & - & - & - & - & - & - & - \\
\hline- & - & - & - & - & - & - & - & - & - \\
\hline \pm & \pm & \pm & + & + & - & + & + & \pm & - \\
\hline+ & + & + & + & + & + & + & + & + & - \\
\hline+ & - & - & - & - & - & - & - & - & - \\
\hline- & - & - & - & - & - & - & - & - & - \\
\hline- & - & - & - & - & - & - & - & - & - \\
\hline+ & + & + & + & + & - & + & + & + & - \\
\hline- & + & - & + & - & - & - & - & - & - \\
\hline+ & - & + & + & - & + & + & + & + & - \\
\hline+ & + & + & + & + & + & + & + & + & + \\
\hline- & - & - & - & - & - & - & - & - & - \\
\hline- & - & - & - & - & - & - & - & + & - \\
\hline- & - & - & + & + & - & - & - & - & - \\
\hline+ & - & + & + & - & - & + & + & + & - \\
\hline- & + & + & + & + & - & + & + & $t$ & - \\
\hline- & - & - & + & - & + & - & - & \pm & - \\
\hline
\end{tabular}


TABLE 7. Tests positive with $R$. maris (group II bacteria) and " $B$. maris" AUCNM B-464

Acid from the following carbohydrates:

Fructose

Glucose

Glycerol

Catalase formation

Cell-wall chemotype $\mathrm{IV}^{a}$

Coccoid and rodlike cells $(0.5$ to $2 \mu \mathrm{m})$ after 16 to $18 \mathrm{~h}$ of incubation on NA and GA

Decomposition of Tweens 20,40,60, and 80

Gram positive

Growth orange and poor on NA, GA, and WA without aerial mycelium

Growth with $\mathrm{C}_{6}, \mathrm{C}_{7}, \mathrm{C}_{9}$ to $\mathrm{C}_{17}$, and $\mathrm{C}_{23} n$-alkanes

Growth with $5 \% \mathrm{NaCl}$

Growth with $7 \% \mathrm{NaCl}$

Nitrate reduction

Presence of lipid LCN-A

Utilization of following substrates:

Acetate

Butyrate

Fumarate

Malate

Pyruvate

Succinate

${ }^{a}$ See footnote $b$ to Table 3 .

unsaturated acids, and a menaquinone, MK$8\left(\mathrm{H}_{2}\right)$, as the major isoprenolog.

A comparison of group II properties with those of the type or reference strains of 10 established Rhodococcus species (Table 6) indicates that the members of group II also belong to a distinct species of Rhodococcus. With respect to the name of this species, the following musi be taken into consideration. On the basis of morphological, cultural, and physiological properties, the isolates of group II may be identified as members of " $B$. maris" (Harrison 1929) Breed 1953 (synonym: "Flavobacterium maris" Harrison 1929) $(8,20)$. The strains closely resemble " $B$. maris" AUCNM B-464 (Tables 69), which has a lipid LCN-A similar to that of $R$. erythropolis NCIB 8863 and a cell wall of chemotype IV; the same wall chemotype was found (44) in another strain of " $B$. maris," viz., AJ 1480 (= IFM S-30).

It is obvious that at present the genus Brevibacterium is a heterogeneous taxon. Some of its members have cell walls of chemotype IV and produce glutamic acid; they were thus named $C$. glutamicum and were considered to be members of the genus Corynebacterium sensu stricto (1). Many other species with ornithine or lysine in the cell wall were transferred from Brevibacterium to either the genus Curtobacterium or the genus Arthrobacter (44). The chemotaxonomic properties mentioned above indicate that " $B$. maris" cannot be classified as a member of the genus Arthrobacter as suggested by Rogosa and
Keddie (33). Gordon (15) has pointed out that strains with the properties of '“ ' $M$.' rhodochrous" may previously have been identified as members of the genus Brevibacterium.

According to Yamada and Komagata (44), only strains of $B$. linens containing meso-DAP in their cell walls can be considered bona fide members of Brevibacterium. Subsequently, other authors have stated that $B$. linens contains ribose but not arabinose or mycolic acids in its cell wall $(12,23,32,35)$.

TABLE 8. Tests negative with $R$. maris (group II bacteria) and " $B$. maris" AUCNM B-464

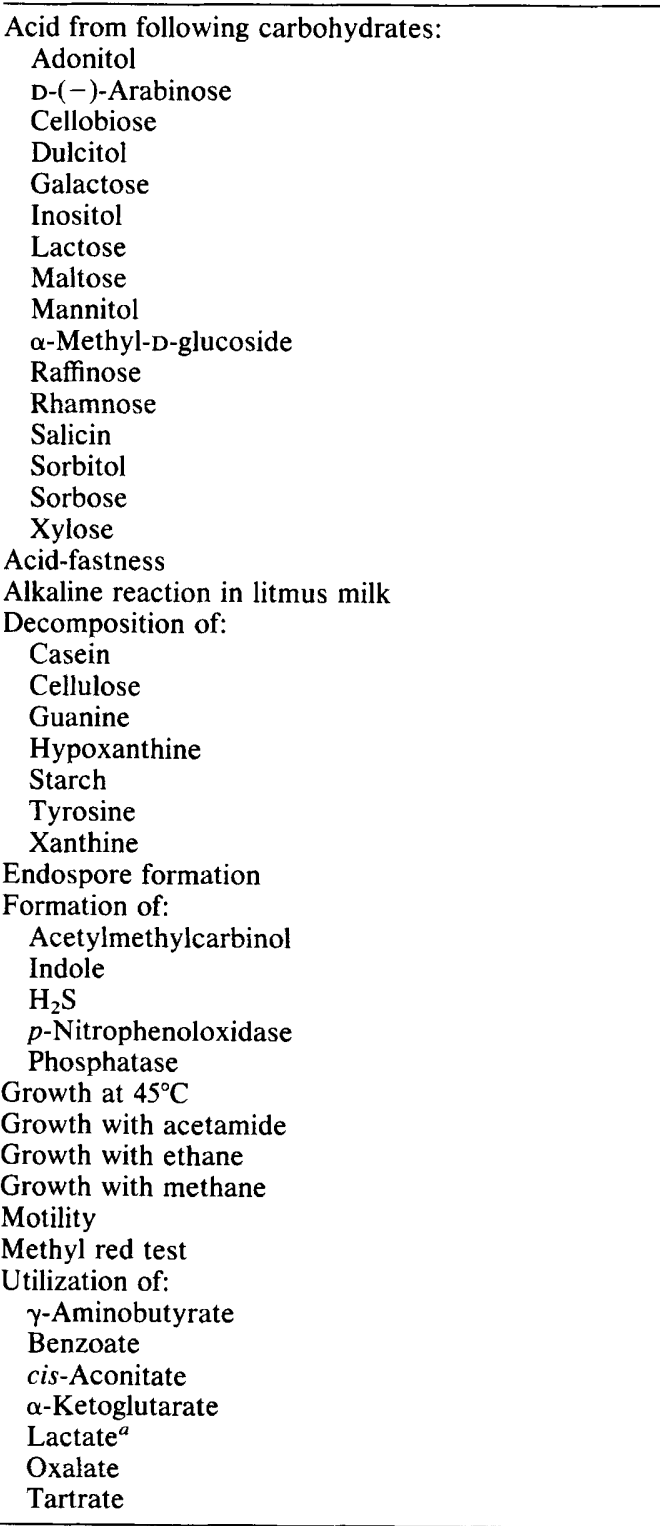

$a$ " $B$. maris" AUCNM B-464 is positive. 
TABLE 9. Tests giving different results with strains of $R$. maris (group II bacteria)

\begin{tabular}{|c|c|c|c|c|}
\hline \multirow[b]{2}{*}{ Characteristic } & \multirow{2}{*}{$\begin{array}{l}\text { No. of } \\
\text { strains } \\
\text { positive }\end{array}$} & \multicolumn{2}{|c|}{ Results with: } & \multirow{2}{*}{$\begin{array}{l}\text { Serial no. of strains } \\
\text { that gave the less } \\
\text { common result }\end{array}$} \\
\hline & & $\begin{array}{l}\text { Type strain } \\
\text { IMV } 195\end{array}$ & $\begin{array}{l}\text { "B. maris" } \\
\text { AUCNM B-464 }\end{array}$ & \\
\hline Acid from mannose & $3 / 6$ & - & - & $\begin{array}{c}35,37,38 \text { are positive; } \\
33,34,36 \text { are negative }\end{array}$ \\
\hline Acid from sucrose & $1 / 6$ & - & - & 35 \\
\hline Citrate utilization & $2 / 6$ & - & - & 35,38 \\
\hline Gelatin liquefaction & $3 / 6$ & - & - & $\begin{array}{c}35,36,38 \text { are positive; } \\
33,34,37 \text { are negative }\end{array}$ \\
\hline Growth with benzamide & $1 / 6$ & - & - & 35 \\
\hline Growth with $\mathrm{C}_{8} n$-alkane & $5 / 6$ & + & + & 34 \\
\hline $\begin{array}{l}\text { Oxidation of glucose in } \\
\text { Hugh and Leifson O-F } \\
\text { medium }\end{array}$ & $1 / 5$ & - & - & 37 \\
\hline $\begin{array}{l}\text { Production of } \mathrm{NH}_{3} \text { from } \\
\text { peptone }\end{array}$ & $3 / 6$ & - & - & $\begin{array}{c}34,36,38 \text { are positive; } \\
33,35,37 \text { are negative }\end{array}$ \\
\hline Urease production & $2 / 6$ & - & + & 35,37 \\
\hline
\end{tabular}

Our data indicate that " $B$. maris" corresponds to the isolates of our group II and that these organisms should be classified as a species of the genus Rhodococcus, for which we propose the name Rhodococcus maris. As with " $M$. luteum," the name "Brevibacterium maris" was not included on the Approved Lists (37). By reason of the same arguments give above for " $M$. luteum," the name $R$. maris should be regarded as a new name.

Strain IMV 195 (= AUCNM A-593) is the type strain of $R$. maris. A description of this strain is presented in Table 6 . (It should be noted that a type or neotype strain was never officially established for "B. maris."')

Tests useful for differentiating $R$. maris and $R$. luteus from each other and from the type or reference strains of 10 established Rhodococcus species $(11,34)$ are given in Table 10.

In contrast to the rhodococci studied by Gordon (15), $R$. maris did not oxidize glucose in Hugh and Leifson medium. The morphological cycle of $R$. maris is characterized by a rapid changing of very short rods into coccoid forms without the formation of primary mycelium.

\section{ACKNOWLEDGMENTS}

We are much indebted to $\mathbf{M}$. Goodfellow, M. Tsukamura D. Jones, T. J. Rowbotham, R. E. Gordon, and I. Komura, who kindly provided the collection strains (Table 2); we thank E. F. Lessel for his invaluable help in the preparation of this manuscript.

\section{REPRINT REQUESTS}

Address reprint requests to: Dr. O. A. Nesterenko, Zabolotny 26, Institute of Microbiology and Virology, $252143 \mathrm{Kiev}$ USSR.

\section{LITERATURE CITED}

1. Abe, S., K. Takayama, and S. Kinoshita. 1967. Taxonomical studies on glutamic acid-producing bacteria. J. Gen. Appl. Microbiol. 13:279-301.
2. Alshamaony, L., M. Goodfellow, and D. E. Minnikin. 1976. Free mycolic acids as criteria in the classification of Nocardia and the "rhodochrous" complex. J. Gen. Microbiol. 92:188-199.

3. Andreev, L. V., and V. P. Galchenko. 1978. Fatty acid composition and identification of methanotrophic bacteria. Dokl. Akad. Nauk SSR 6:1465-1469.

4. Aristovskaya, T. V., M. E. Vladimirskaya, M. M. Gollerbach, G. A. Katanskaya, et al. 1962. In G. L. Seliber (ed.), Great practicum on microbiology. Higher School, Moscow.

5. Batrakov, S. G., A. G. Panosyan, B. V. Rosynov, I. V. Konova, and L. D. Bergelson. 1976. Menaquinones of Actinomyces olivaceus: on the structures of $\mathrm{MK}-9\left(\mathrm{H}_{6}\right)$, MK- $9\left(\mathrm{H}_{2}\right)$, MK-8 $\left(\mathrm{H}_{6}\right)$ and $\mathrm{MK}-8\left(\mathrm{H}_{8}\right)$. Bioorg. Chem. USSR 2:1538-1550.

6. Bönicke, R., and S. E. Juhasz. 1965. Methode de differenciation du genre "mycobacterium" et du genre "nocardia." Bull. Int. Un. Tuberk. 36:14-20.

7. Bousfield, I. J., and M. Goodfellow. 1976. The "rhodochrous" complex and its relationship with allied taxa, p. 39-65. In M. Goodfellow, G. H. Brownell, and J. A. Serrano (ed.), The biology of the nocardiae. Academic Press, London.

8. Breed, R. S. 1957. Family IX. Brevibacteriaceae Breed. 1953, p. 490-503. In R. S. Breed, E. G. D. Murray, and N. R. Smith (ed.), Bergey's manual of determinative bacteriology, 7th ed. The Williams \& Wilkins Co., Baltimore.

9. Cross, T., and M. Goodfellow. 1973. Taxonomy and classification of the actinomycetes, p. 11-112. In G. Sykes and F. A. Skinner (ed.), Actinomycetales: characteristics and practical importance. Academic Press, London.

10. Giane-Williams, D. J., and T. M. Skerman. 1966. Comparative studies on coryneform bacteria from milk and dairy sources. J. Appl. Bacteriol. 29:72-92.

11. Goodfellow, M., and G. Alderson. 1977. The actinomycete-genus Rhodococcus: a home for the "rhodochrous" complex. J. Gen. Microbiol. 100:99-122.

12. Goodfellow, M., M. D. Collins, and D. E. Minnikin. 1976. Thin-layer chromatographic analysis of mycolic acid and other long-chain components in whole-organism methanolysates of coryneform and related taxa. J. Gen. Microbiol. 96:351-358.

13. Goodfellow, M., and D. E. Minnikin. 1978. Numerical and chemical methods in the classification of Nocardia and related taxa, p. 43-51. In M. Mordarski, W. Kurylowicz, and J. Jeljaszewicz (ed.), Nocardia and Streptomyces. Gustav Fischer Verlag, Stuttgart.

14. Goodfellow, M., D. E. Minnikin, P. V. Patel, and H. 


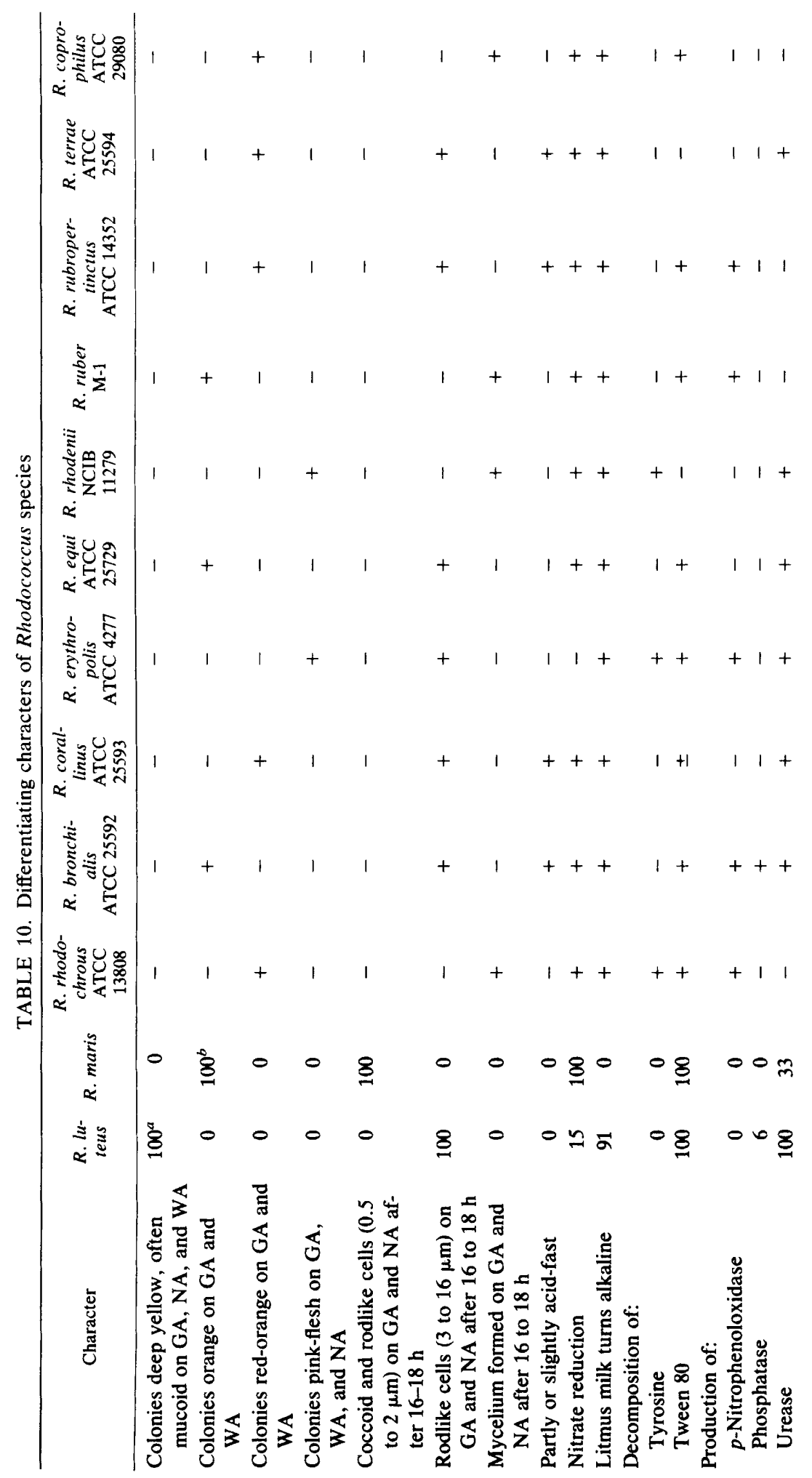




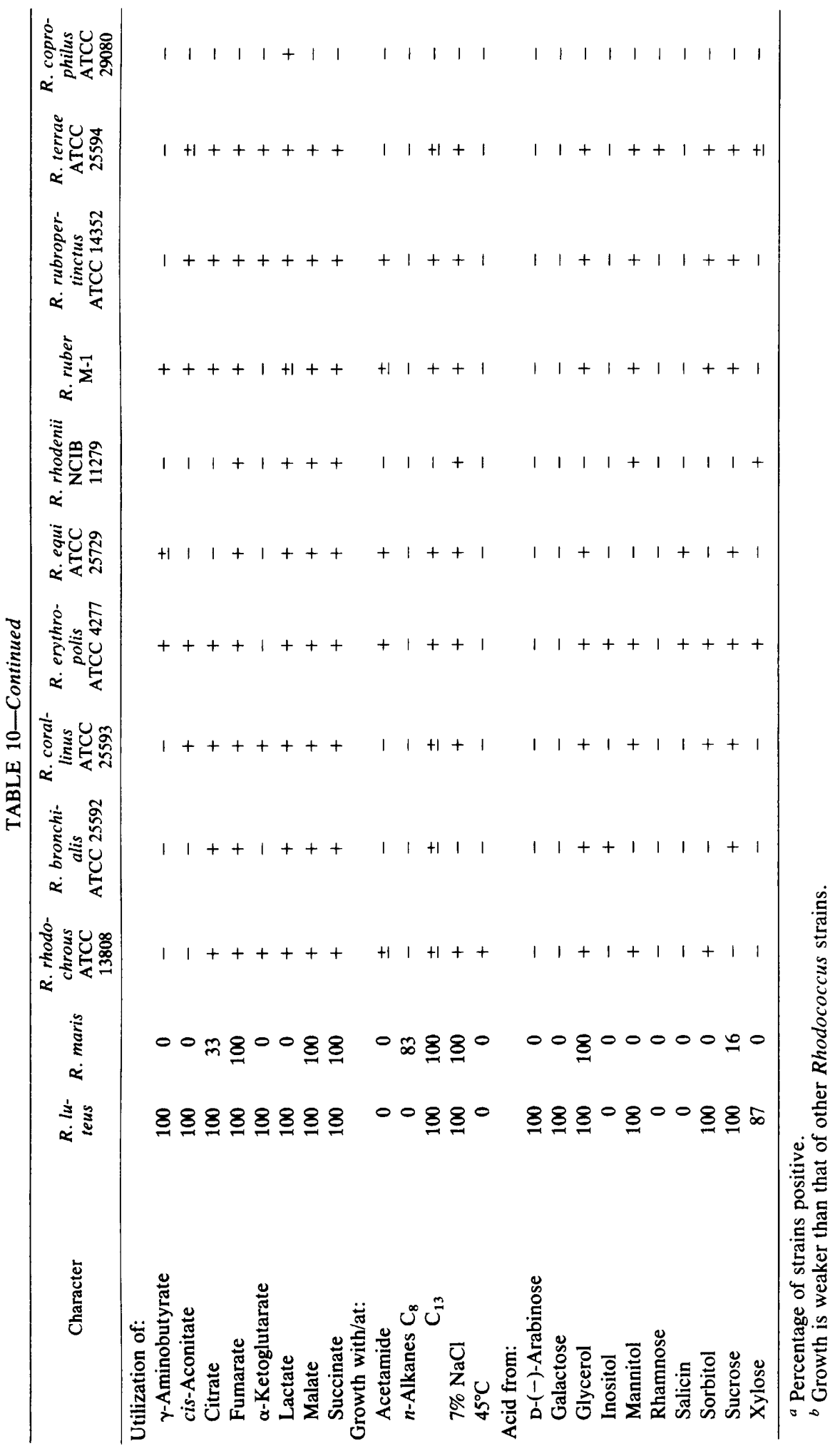


Mordarska. 1973. Free nocardomycolic acids in the classification of nocardiae and strains of the "rhodochrous" complex. J. Gen. Microbiol. 74:185-188.

15. Gordon, R. E. 1966. Some strains in search of a genusCorynebacterium, Mycobacterium, Nocardia or what? J. Gen. Microbiol. 43:329-343.

16. Gordon, R. E., and J. M. Mihm. 1957. A comparative study of some strains received as nocardiae. J. Bacteriol. 73:15-27.

17. Gordon, R. E., and J. M. Mihm. 1959. A comparison of four species of mycobacteria. J. Gen. Microbiol. 21:736748 .

18. Gordon, R. E., and M. M. Smith. 1953. Rapidly growing, acid-fast bacteria. I. Species descriptions of Mycobacterium phlei Lehmann and Neumann and Mycobacterium smegmatis (Trevisan) Lehmann and Neumann. J. Bacteriol. 66:41-48.

19. Gordon, R. E., and M. M. Smith. 1955. Rapidly growing, acid fast bacteria. II. Species description of Mycobacterium fortuitum Cruz. J. Bacteriol. 69:502-507.

20. Harrison, F. C. 1929. The discoloration of halibut. Can. J. Res. 1:214-239.

21. Hugh, R., and E. Leifson. 1953. The taxonomic significance of fermentative versus oxidative metabolism of carbohydrates by various gram-negative bacteria. J. Bacteriol. 66:24-26.

22. Kasumova, S. A., B. V. Rosinov, T. V. Koronelli, E. I. Kvasnikov, and O. A. Nesterenko. 1976. Nocardomycolic acids of Mycobacterium rhodochrous NCTC 576. Scientific Report, Higher School, Biological Sciences, Moscow State University, Moscow.

23. Keddie, R. M., and G. L. Cure. 1977. The cell wall composition and distribution of free mycolic acids in named strains of coryneform bacteria and in isolates from various natural sources. J. Appl. Bacteriol. 42:229-252.

24. Komagata, K., K. Yamada, and H. Ogawa. 1969. Taxonomic studies on coryneform bacteria. I. Division of bacterial cells. J. Gen. Appl. Microbiol. 15:243-259.

25. Krasil'nikov, N. A. 1949. Identification of bacteria and actinomycetes (in Russian). Akademii Nauk SSSR, Moscow.

26. Kvasnikov, E. I., E. F. Solomko, O. A. Nesterenko, and N. I. Pavlenko. 1972. Utilization of volatile n-alkanes $\left(C_{6}-\right.$ $\mathrm{C}_{10}$ ) by bacteria. Microbiology (USSR) 41:586-591.

27. Lechevalier, M. P. 1976 . The taxonomy of the genus Nocardia: some light at the end of the tunnel?, p. 1-38. In M. Goodfellow, G. H. Brownell, and J. A. Serrano (ed.), The biology of the nocardiae. Academic Press, London.

28. Minnikin, D. E., M. Goodfellow, and M. D. Collins. 1978. Lipid composition in the classification and identification of coryneform and related taxa, p. 85-160. In I. J. Bousfield and A. G. Callely (ed.), Coryneform bacteria. Academic Press, London.

29. Minnikin, D. E., P. Patel, and M. Goodfellow. 1974. Mycolic acids of representative strains of Nocardia and "rhodochrous" complex. FEBS Lett. 39:322-324.

30. Mordarska, H., M. Mordarski, and M. Goodfellow. 1972.
Chemotaxonomic characters and classification of some nocardioform bacteria. J. Gen. Microbiol. 71:77-86.

31. Nesterenko, O. A., S. A. Kasumova, E. I. Kvasnikov, and V. V. Shkaruba. 1976. Chemotaxonomic characteristics of bacteria belonging to the genus Nocardia isolated from Ukrainian soil. Microbiology (USSR) 45:831-838.

32. Nesterenko, O. A., T. M. Nogina, and E. I. Kvasnikov. 1978. Chemotaxonomic characters of some coryneform bacteria and representatives of the "rhodochrous" complex. Microbiology (USSR) 47:1055-1062.

33. Rogosa, M., and R. M. Keddie. 1974. Genus A. Brevibacterium Breed 1953, 13, p. 625-628. In R. E. Buchanan and N. E. Gibbons (ed.), Bergey's manual of determinative bacteriology, 8th ed. The Williams \& Wilkins Co., Baltimore.

34. Rowbotham, T. J., and T. Cross. 1977. Rhodococcus coprophilus sp. nov.: an aerobic nocardioform actinomycete belonging to the "rhodochrous" complex. J. Gen. Microbiol. 100:123-138.

35. Schleifer, K. H., and O. Kandler. 1972. Peptidoglycan types of bacterial cell walls and their taxonomic implications. Bacteriol. Rev. 36:407-477.

36. Sierra, G. 1957. A simple method for the detection of lipolytic activity of microorganisms and some observations on the influence of the contact between cells and fatty substrates. Antonie van Leeuwenhoek J. Microbiol. Serol. 23:15-22.

37. Skerman, V. B. D., V. McGowan, and P. H. A. Sneath (ed.). 1980. Approved lists of bacterial names. Int. J. Syst. Bacteriol. 30:225-420.

38. Society of American Bacteriologists Committee on Bacteriologic Technic. 1957. Manual of microbiological methods McGraw-Hill Book Co., New York.

39. Söhngen, N. L. 1913. Benzin, Petroleum, Paraffinöl und Paraffin als Kohlenstoff- und Energie-quelle für Mikroben. Zentralbl. Bakteriol. Parasitenkd. Infektionskr. Hyg. Abt. 2 37:595-609.

40. Sneath, P. H. A., and V. B. D. Skerman. 1966. A list of type and reference strains of bacteria. Int. J. Syst. Bacteriol. 16:1-333.

41. Sukapure, R. S., M. P. Lechevalier, H. Reber, M. L. Higgins, H. A. Lechevalier, and H. Prauser. 1970. Motile nocardioid Actinomycetales. Appl. Microbiol. 19:527533.

42. Tsukamura, M. 1967. Identification of mycobacteria. Tubercle 48:311-338.

43. Tsukamura, M. 1971. Proposal of a new genus, Gordona, for slightly acid-fast organisms occurring in sputa of patients with pulmonary disease and in soil. J. Gen. Microbiol. 68:15-26.

44. Yamada, K., and K. Komagata. 1972. Taxonomic studies of coryneform bacteria. V. Classification of coryneform bacteria. J. Gen. Appl. Microbiol. 18:417-431.

45. Yamada, K., J. Takahashi, K. Kobayashi, and Y. Imada. 1963. Studies on utilization of hydrocarbons by microorganisms. Agric. Biol. Chem. 27:390-395. 